Western University Scholarship@Western

Geography Publications

Geography Department

2017

\title{
Urbanizing Physical Geography
}

Peter Ashmore

pashmore@uwo.ca

Belinda Dodson

Follow this and additional works at: https://ir.lib.uwo.ca/geographypub

Part of the Geography Commons

Citation of this paper:

Ashmore, Peter and Dodson, Belinda, "Urbanizing Physical Geography" (2017). Geography Publications. 358.

https://ir.lib.uwo.ca/geographypub/358 


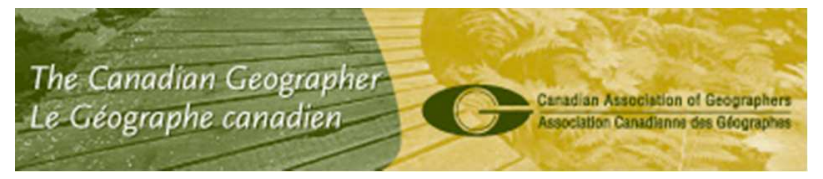

\section{Urbanizing physical geography}

\begin{tabular}{|r|l|}
\hline Journal: & THE CANADIAN GEOGRAPHER / LE GÉOGRAPHE CANADIEN \\
\hline Manuscript ID & 03-16-TCG-360.R1 \\
\hline Wiley - Manuscript type: & Dialogue \\
\hline Keywords: & physical geography, urban physical geography, socio-nature, urbanization \\
\hline Abstract: & $\begin{array}{l}\text { The physical environment of cities and processes of urbanization have a } \\
\text { long-standing presence in the field of physical geography and can give } \\
\text { physical geography a renewed relevance in urban sustainability and } \\
\text { planning. Existing approaches in physical geography will be a valuable } \\
\text { component of this work. New insights and understanding of urban } \\
\text { environments may be gained by engaging with ideas of urban landscapes } \\
\text { as socio-natures; adopting critical, political and reflexive modes of thought } \\
\text { and practice; and thinking beyond the physical structures and spatial } \\
\text { boundaries of the city to planetary urbanization. Thinking about urban } \\
\text { environments in these ways also opens up possible changes in the scope of } \\
\text { and approaches to physical geography as a whole. }\end{array}$ \\
\hline \multicolumn{2}{|l}{} \\
\hline
\end{tabular}




\begin{abstract}
:
The physical environment of cities and processes of urbanization have a long-standing presence in the field of physical geography and can give physical geography a renewed relevance in urban sustainability and planning. Existing approaches in physical geography will be a valuable component of this work. New insights and understanding of urban environments may be gained by engaging with ideas of urban landscapes as socio-natures; adopting critical, political and reflexive modes of thought and practice; and thinking beyond the physical structures and spatial boundaries of the city to planetary urbanization. Thinking about urban environments in these ways also opens up possible changes in the scope of and approaches to physical geography as a whole.
\end{abstract}

Keywords: physical geography, urban physical geography, socio-nature, urbanization.

\title{
Key message:
}

- There is a growing interest in, and an expanding role and necessity for, physical geography in urban settings, much of which can usefully build on well-established approaches in physical geography

- Conceiving urban landscapes as socio-natures opens up new avenues for physical geography research, and ideas of planetary urbanism open the possibility that all physical geography is urban

- Adopting a wider range of approaches through urban physical geography leads to potential changes in the scope and nature of physical geography itself. 
Cities have long been sites of engagement for physical geographers, in some sub-disciplines more than others, but there are opportunities for urban physical geography to be a more prominent theme within the discipline and to expand the scope of engagements with urban geographies more generally. Syntheses of the physical environment of cities and of modification of earth surface environments by urbanization reflect a long-standing interest in this theme within physical geography (e.g. Douglas, 1983) as do seminal and influential papers in this realm (e.g. Wolman, 1967). There is also a significant body of work on issues such as hazards in urban settings (e.g. Cooke, 1984) and risk and resilience in relation to, for example, climate change (e.g. Pelling and Blackburn, 2014). Furthermore, a strong thread runs through physical geography on the theme of the impact of human activity on 'natural' systems of all kinds and of anthropogenic aspects of the bio-physical environment, appearing most recently under the banner of the Anthropocene (see, for example the recent AAG Symposium Physical geography: challenges of the Anthropocene).These examples point to further possibilities for physical geographers to engage with urban environments, to expand conceptualizations of cities and their varied forms, and to develop more prominence for this work. Here we propose some possible forms of engagement that collectively provide a rationale and provocation for expanding thinking by physical geographers about cities, urbanization and understandings of the urban.

Gregory's (2000, p. 9) general proposition that physical geography focusses on the “...character of, and processes shaping, the land-surface of the earth and its envelope, emphasising the spatial variations... and temporal changes necessary to understand the environments of the earth... and to understand how Earth's physical environment is the basis for, and affected by, human activity" provides a useful general idea of the accepted scope and goals 
of physical geography. Physical geography has approached this scientifically in the sense of standing apart from its subject to seek some form of correspondence or coherence truth about the real, independently-existing non-human world. From this position humans are typically seen as perturbing and modifying an independent nature. The designed and (physically) constructed forms of cities are artificial and unnatural and therefore may not be seen as amenable to analysis within the normally accepted scope and paradigms of physical geography. Here, perhaps, lies reluctance among some physical geographers to think about the city as a landscape and urban environments and processes more generally (Francis et. al, 2011) But this need not be a barrier for physical geography and at the same time urban environments provide a venue for developing new approaches to the core goals of physical geography, and an expanded role in urban geography and the discipline as a whole.

One approach to the physical geographer's dilemma about the artificiality of urban forms is to simply take them as they are, as shown, for example, in Douglas' (1983) book on urban environments. Urban landscapes are as real and, some would argue, as natural as any other and yet there is scope for much greater understanding of their characteristics, function and development. Rather than seeing them as degraded forms of the natural and non-urban, urban landscapes can simply be viewed as a valid object of study, as open to conceptual, empirical and theoretical knowledge as any other landscape while offering novel characteristics and processes (Francis et al., 2011). This approach is already well-established within sub-fields of physical geography. For example, there is a wealth of research of this kind in biogeography and ecology, to the extent that urban ecology is a large and recognized research specialization which to some extent has subsumed elements of physical geography (Douglas et al., 2011) including issues such as biodiversity and primary production in urban areas (Imhof et al., 2004; Faeth et al., 2012) and 
extending into issues of, for example, ecological restoration. Urban hydro-climatologists habitually take building materials, dimensions, and urban surface topography as a given (e.g. the classic urban canyon or impervious watershed), use standard hydro-climatological observational methods and modeling approaches and apply them to the phenomena of urban climate following normal scientific paradigms (Grimmond et al., 2010). The same is true to a more limited extent in geomorphology where, in addition to studying urban geomorphic hazards and landform response to urbanization, there is also a body of work on the characteristics of anthropogenic landforms (Thornbush, 2015). We might refer to this, and similar examples in other sub-fields of physical geography, as traditional urban physical geography - taking the environment and structures as a given and studying their characteristics using established methods also used in many other environments. This includes using conventional measurement systems and remote sensing methods to provide the core scientific observations. Extensive opportunities remain for pursuing these themes and for developing explanations of urban environments following this paradigm. There is also new potential for giving the whole field more prominence in the light of re-engagement in issues of urban sustainability and a tradition of applying research outcomes in urban planning and design, which continues to be an important motivation and role for work in urban physical geography. This potential is signalled, for example, by identification of a specifically urban goal (Goal 11) in the recently launched UN Sustainable Development Goals, indicative of a focus on cities as social, economic, political and environmental systems that are home to more than half the world's population.

While there is ample opportunity in traditional forms of urban physical geography, if we venture outside the normal scope of physical geography then cities offer intriguing rationales, possibilities and ideas that have the potential to invigorate the study of urban environments, 
provide a means of making physical geography influential in other fields of urban studies, and open up more critical avenues within physical geography (Lave et al., 2014). Urban landscapes are perhaps the most obvious, and necessary, places for some new forms of engagement in physical geography. The observation that cities are complex interactions of bio-physical, social, economic, and political processes and systems has been made many times. Douglas (1983, p. 206), with some apparent indignation, goes so far as to say that to learn about cities without considering both the biophysical environment and the social environment is "downright unscholarly". However, despite frequent calls to connect the bio-physical to the social, physical geographers seldom make this socio-natural connection (Francis et al., 2011; Ashmore, 2015). This reluctance arises because it partly entails stepping outside the normal comfort zone of objectively observing a separate nature. Accepting a view in which social and natural processes mutually interact in space and time to produce socio-natures, rather than human decisions and actions having an impact on a separate natural environment, is part of this transition. It is one that has the potential for deeper understanding of urban environments but it also requires some philosophical shifts in the norms and practices of physical geography. Greater consideration of the role of institutional decision making and cultures in making the urban environment (e.g. Conway and VanderVecht, 2015) is one step in this direction towards understanding the socionatural co-production of urban landscapes. This shift also requires a loosening of physical geography's normative epistemological generalization, to encompass knowledge production that admits both the study of particular places and the examination of changes over time that are contextual and contingent rather than predictable or replicable.

Urban river morphology, to take one example, can be understood more deeply by recognising that urban rivers are complexly organised, highly contingent and tightly coupled 
ecosystems patterned around historical events, human agents and social structures (Orsi, 2004) and by recognising the importance of place and circumstance in the particular socio-natural outcome. River morphology, social and political actions affecting the river, and human conceptions of the river co-evolve along a particular, place-specific path. Urban rivers are therefore social artefacts as much as natural features. Activities such as river restoration are also embedded within this socio-natural system. Interventions by, for example, fluvial geomorphologists are similarly embedded, making illusory the position of neutral outside observer of the system. This becomes even more apparent when physical geographers and others consciously design urban environments. Explicit interventions, such as deliberately increasing the supply of urban green space or engaging in ecological restoration, may have both intended and unintended feedbacks in the socio-natural system. For example, Wolch et al. (2014) cite examples in which green space provision has led to changes in property values and displacement of residents who were the intended beneficiaries. This shift to thinking through the socio-natural, co-production of urban environments may be a radical shift for many but seems to offer essential insight and necessary engagement of physical geography with human systems. It also renders more transparent and explicit the incorporation of physical geographers as actors in various social and political institutions, whether intentionally and directly as advisors and consultants or indirectly through producing research that informs decision-making in urban planning and design (Tadaki et al., 2014, 2015).

More radical and critical approaches are possible. If cities are "dense networks of interwoven socio-spatial processes that are simultaneously local and global, human and physical, cultural and organic" (Heynen et al., 2006), an even fuller engagement with the socio-political may be fruitful. An established tradition of urban political ecology provides some basis for this 
although it has tended to engage more with the political than the ecological while newer, but related, conceptions labeled as "critical physical geography” have understanding and explaining the environment as a primary focus (Lave at al., 2014; McClintock, 2015). Socio-natural processes can be examined as the outcome of socio-political forces leading to a material politics of place. For example, McClintock (2015) uses this approach in explaining patterns of lead accumulation in urban soils in Oakland, California. While geology and pedogenesis are an essential part of the story, the soil characteristics are also material (hybrid) manifestations of historically contingent socio-political events and circumstances, and of spatially uneven, and shifting, capital accumulation. There is mutual feedback so that lead accumulation in soils leads to socio-spatial devaluation and segregation, which in turn generates activists' responses for soil remediation that further modify the soils and, in this case, produced an entirely new lead species in the soils. These events are simultaneously local and distal, social and natural. They play out in a particular time and place. This challenges any notion that cities are serially replicated in different locations, that cities are easily definable as an entity or structure, and that urbanization is monolithic and uniform. This, in turn, may unsettle traditional physical geographers' comfort with the idea of seeking universality, of explicitly bounding physical entities or spatial scales for study, and working with relatively flat empirical ontologies and rationalities. Such unsettling does not foreclose generalization but opens possibilities for other forms of comparative and accumulative epistemologies across the full range of urban forms and locations.

The possibilities for urban physical geography that we have outlined above can be seen as (a) applying physical geography to the city as setting, scale or system, and (b) encouraging physical geographers to pay greater attention to the social processes that, acting together with nature, produce urban environments, or socio-natures. Each of these possible directions remains 
conceptually within conventional understandings of the urban, even as they make a case for physical geography to move beyond the solely natural. To these we would add another possibility for urbanizing physical geography, one that is at once more radical and yet also already familiar to physical geographers, if in different terms. Urban geographers are debating and theorizing what has been termed 'planetary urbanism' (Brenner 2013, Brenner and Schmid 2015). This rescaling takes the idea of the urban beyond the city to think, rather, in terms of what constitutes urbanization or the urban condition more generally. Within this line of thinking, the urban is seen as existing at the global, planetary scale as opposed to only within bounded entities defined or designated as a city. Environmental concerns, although not the only motive behind this conceptual and theoretical rescaling, are certainly a key component. Two of the leading scholars within urban political ecology, Eric Swyngedouw and Maria Kaika (2014, p. 462-3), express it thus: "We are, therefore, not so much concerned with the question of nature IN the city, but rather with the urbanization OF nature, i.e. the process through which all types of nature are socially mobilized, economically incorporated (commodified), and physically metabolized/transformed in order to support the urbanization process". Perhaps, in this sense, all physical geography is now urban physical geography, whether within or outside cities.

A scalar shift to planetary urbanism has some parallels with the idea of the Anthropocene, a framing that might be more familiar and comfortable for many physical geographers. Planetary urbanism certainly presents intriguing possibilities for collaboration, conversation and constructive mutual critique between human and physical geographers. It also unshackles both urban physical and urban human geography from "methodological cityism" (Angelo and Wachsmuth 2014, p. 19) to think about the processes by which both cities and nature are conceptually and materially produced at multiple scales. Rescaling of the urban 
reinforces recent calls (e.g. O’Brien, 2010, Castree, 2015) for geographers to engage more broadly, deeply, integratively and politically with the issues of global change science, and so change the nature of global change research along with the nature, scope and role of physical geography.

It is curious that urban geography as a specialization has been seen within geography as tacitly the preserve of human geographers. We have outlined some possibilities for how physical geography might be more urban. This is presented not as some sort of manifesto, but to highlight multiple pathways toward multiple urban physical geographies. Besides reasons of social relevance and political urgency, there are sound scientific motives for conducting more physical geography research in urban contexts, incorporating the socio-political into understanding of urban environments, and extending the scale and scope of urban physical geography beyond cities. 


\section{Acknowledgements}

We thank Marc Tadaki and two anonymous reviewers for their comments on the draft of this paper.

\section{References}

Angelo, H. and Wachsmuth, D. 2015. Urbanizing urban political ecology. International Journal of Urban and Regional Research 39: 16-27.

Ashmore, P. 2015. Towards a socio-geomorphology of rivers. Geomorphology 241: 149-156.

Brenner, N. (ed.). 2013. Implosions/Explosions: Towards a Study of Planetary Urbanization. Berlin: Jovis.

Brenner, N. and Schmid, C. 2015. Towards a new epistemology of the urban? City 19: 151-182.

Castree, N. 2015. Geographers and the discourse of an Earth transformed: influencing the intellectual weather or changing the intellectual climate? Geographical Research 53: 244254.

Conway, T.M. and J. Vander Vecht, J. 2015. Growing a diverse urban forest: species selection decisions by practitioners planting and supplying trees. Landscape and Urban Planning 138: $1-10$.

Cooke, R.U. 1984. Geomorphological Hazards in Los Angeles. London. George Allen \& Unwin. Douglas, I. 1983. The Urban Environment. London: Edward Arnold.

Douglas, I, Goode, D., Houck, M.C., and Wang, R. (Editors). 2011. The Routledge Handbook of Urban Ecology. Routledge. Abingdon and New York. 
Faeth, S. H., Saari, S. and Bang, C. 2012. Urban Biodiversity: Patterns, Processes and Implications for Conservation. eLS (Encyclopedia of Life Sciences). DOI:10.1002/9780470015902.a0023572.

Francis, R. A., Lorimer, J. and Raco, M. 2012. Urban ecosystems as 'natural' homes for biogeographical boundary crossings. Transactions of the Institute of British Geographers, 37: $183-190$.

Gregory, K.J. 2000. The Changing Nature of Physical Geography. London: Edward Arnold.

Grimmond, C.S.B., Roth, M., Oke, T.R., Au, Y.C., Best, M., Betts, R., Carmichael, G., Cleugh, H., Dabberdt, W., Emmanuel, R., Freitas, E., Fortuniak, K., Hanna, S., Klein, P., Kalkstein, L.S., Liu, C.H., Nickson, A., Pearlmutter, D., Sailor, D. and Voogt, J. 2010. Climate and More Sustainable Cities: Climate Information for Improved Planning and Management of Cities (Producers/Capabilities Perspective). Procedia Environmental Sciences 1: 247-274.

Heynen, N., Kaika, M., and Swyngedouw, E. 2006. Urban political ecology: politicizing the production of urban natures. In In the Nature of Cities: urban political ecology and the politics of urban metabolism, eds. N. Heynen, M. Kaika and E. Swyngedouw. London: Routledge, 21-40.

Imhoff,M.L., Bounoua,L., DeFries,R., Lawrence,W.T., Stutzer,D., Tucker,C.J., and Ricketts,T. 2004. The consequences of urban land transformation on net primary productivity in the United States. Remote Sensing of Environment 89: 434-443. 
Lave, R. Wilson, M.W., Barron, E.S., Biermann, C., Carey, M.A., Duvall, C.S., Johnson, L., Lane, K.M., McClintock, N., Munroe, D., Pain, R., Proctor, J., Rhoads, B.L., Robertson, M.M., Rossi, J., Sayre, N.F., Simon, G., Tadaki, M., Van Dyke, C. 2014. Intervention: Critical physical geography. Canadian Geographer 58: 1-10.

McClintock, N. 2015. Critical physical geography of urban soil contamination. Geoforum 65: 6985.

O’Brien, K., 2010. Responding to environmental change: a new age for human geography? Progress in Human Geography 35: 542-549.

Orsi, J. 2004. Hazardous Metropolis: Flooding and urban ecology in Los Angeles. Berkeley: University of California Press.

Pelling, M. and Blackburn, S. 2014. Megacities and the coast: Risk, resilience and transformation. New York: Routledge.

Swyngedouw, E., and Kaika, M. 2014. Urban political ecology: Great promises, deadlock...and new beginnings? Documents d'Anàlisi Geogràfica 60(3): 459-481

Tadaki, M., Brierley, G. and Cullum, C. 2014. River classification: theory, practice, politics. WIREs Water, 1, 349-367.

Tadaki, M., Brierley, G., Dickson, M., Le Heron, R., Salmond, J., 2015. Cultivating critical practices in physical geography. The Geographical Journal 181: 160-171.

Thornbush, M. 2015. Geography, urban geomorphology and sustainability. Area 47: 350-353. 
Wolch, J.R., Byrne, J., and Newell, J.P. 2014. Urban green space, public health, and environmental justice: The challenge of making cities ‘just green enough'. Landscape and Urban Planning 125: 234-244.

Wolman, G. (1967). A cycle of sedimentation and erosion in urban river channels. Geografiska Annaler 49A: 385-395. 